\title{
CAPACITY BUILDING PERAN SERTA MASYARAKAT DALAM PENANGGULANGAN BENCANA DI DAERAH WISATA KABUPATEN BANYUWANGI DALAM RANGKA MENDUKUNG DESA/ KELURAHAN TANGGUH BENCANA (DESTANA) TAHUN 2017
}

\author{
CAPACITY BUILDING ROLE OF COMMUNITY IN DISASTER MANAGEMENT IN BANYUWANGI \\ DISTRICT AREA IN ORDER TO SUPPORT VILLAGE/TANGGUH BENCANA VILLAGE (DESTANA) 2017
}

\author{
Setya Haksama \\ Fakultas Kesehatan Masyarakat \\ Diansanto Prayoga \\ Program Study Kesehatan Masyarakat PSDKU \\ Syifa'ul Lailiyah \\ Program Study Kesehatan Masyarakat PSDKU \\ Jayanti Dian Eka Sari \\ Program Study Kesehatan Masyarakat PSDKU
}

\begin{abstract}
ABSTRAK
Kabupaten Banyuwangi diterjang tsunami pada tahun 1994 dengan ketinggian 13,9 m akibat gempa 7,2 SR pada kedalaman $33 \mathrm{~km}$. Kabupaten Banyuwangi termasuk kelas rawan tinggi dengan peringkat 163 Nasional berdasarkan Indeks rawan bencana Indonesia 2011. Disamping berkembangnya pariwisata di Kabupaten Banyuwangi, perlu diperhatikan juga Indeks Rawan Bencana tersebut. Peran serta masyarakat dibutuhkan untuk mendukung Kabupaten/Kecamatan/Desa Tangguh Bencana. Tujuan kegiatan ini adalah Memberikan edukasi dan mendemonstrasikan tentang peran serta masyarakat dalam penanggulangan bencana di daerah wisata Kabupaten Banyuwangi untuk mendukung Desa/ Kelurahan Tangguh Bencana (DESTANA). Metode kegiatan melalui pelatihan. Peserta pelatihan ini terdiri dari perangkat Desa/Kelurahan dari Kecamatan Licin, Kalipuro, dan Wongsorejo; dan pemandu wisata (Tour Guide) dari Agen Perjalanan Wisata (Tourism Travel Agency). Kegiatan dilaksanakan di Balai Diklat PNS Licin Kabupaten Banyuwangi. Data dikumpulkan melalui pretest, post test dan observasi. Data dianalisis secara deskriptif. Pelatihan ini dibagi menjadi dua tahap yaitu tahap paparan materi dan simulasi. Narasumber berasal dari Universitas Airlangga, Dinas Kebudayaan dan Pariwisata Kabupaten Banyuwangi, Balai Besar Konservasi Sumber Daya Alam (KSDA) dan Badan Penanggulangan Bencana Daerah (BPBD) Kabupaten Banyuwangi. Tingkat keberhasilan kegiatan pengabdian kepada masyarakat yaitu tercapainya tujuan pertama "Memberikan edukasi tentang peran serta masyarakat dalam penanggulangan bencana di daerah wisata Kabupaten Banyuwangi untuk mendukung DESTANA" sebesar 90\% dan tujuan kedua "Mendemonstrasikan tentang peran serta masyarakat dalam penanggulangan bencana di daerah wisata Kabupaten Banyuwangi untuk mendukung DESTANA" sebesar 107\%. Kegiatan pengabdian kepada masyarakat ini mampu meningkatkan pengetahuan dan keterampilan masyarakat di daerah wisata tentang peran serta masyarakat dalam penanggulangan bencana di daerah wisata Kabupaten Banyuwangi untuk mendukung DESTANA.
\end{abstract}

Kata kunci: peran serta masyarakat, DESTANA, Banyuwangi

\section{ABSTRACT}

Banyuwangi district was hit by a tsunami in 1994 with a height of $13.9 \mathrm{~m}$ due to the 7.2 SR earthquake at a depth of $33 \mathrm{~km}$. Banyuwangi district included high grade class with national rank 163 based on Indonesia Disaster Prone Index 2011. Besides the development of tourism in Banyuwangi district, it was also worth noting also the Index of Disaster Prone. Community participation was needed to support District/Sub-district/ Village of Disaster Resilience. The purpose of this activity was to provide education and demonstrate about community participation in disaster management in tourist area of Banyuwangi District to support Disaster 
Resilience Village (DESTANA). Methods was training activities. The participants of this training consisted of village from Licin, Kalipuro and Wongsorejo sub-districts; and tour guides (Tour Guide) from Travel Agency (Tourism Travel Agency). The activity was held at Banyuwangi District Public Service Training Center. Data were collected through pretest, post test and observation. Data were analyzed descriptively. The training was divided into two stages, namely the stage of material exposure and simulation. The speakers came from Airlangga University, Culture and Tourism Office of Banyuwangi District, Natural Resource Conservation Center (KSDA) and Regional Disaster Management Agency (BPBD) of Banyuwangi District. The success rate of community service activities was the achievement of the first objective "Providing education about community participation in disaster management in Banyuwangi District to support DESTANA" by $90 \%$ and second goal "Demonstrate about community participation in disaster management in Banyuwangi District tourism area for supporting DESTANA "by 107\%. Community service activities were able to improve the knowledge and skills of the community in the tourist area about the participation of the community in disaster management in the tourist area of Banyuwangi District to support DESTANA.

Keywords: Community Participation, DESTANA, Banyuwangi.

\section{PENDAHULUAN}

Kabupaten Banyuwangi memiliki wilayah seluas 5.782,50 $\mathrm{km} 2$ dengan panjang garis pantai membentang mulai dari kecamatan Wongsorejo di sebelah utara sampai dengan Kecamatan Pesanggaran di bagian selatan diperkirakan mencapai 175,8 Kilometer. Mengingat kondisi geografis yang memiliki potensi terjadinya bencana alam serta kondisi demografis yang memiliki potensi terjadinya bencana sosial (BPBD Kabupaten Banyuwangi, 2017). Pada tahun 1994 Kabupaten Banyuwangi diterjang tsunami dengan ketinggian 13,9 m akibat gempa 7,2 SR pada kedalaman $33 \mathrm{~km}$. Berikut ini data Indeks Rawan Bencana Kabupaten Banyuwangi menurut Badan Nasional Penanggulangan Bencana (BNPB) (2011).

1. Indeks rawan bencana Indonesia 2011: Kabupaten Banyuwangi skor 67 (kelas rawan tinggi dengan peringkat 163 Nasional)

2. Indeks rawan bencana gempa bumi dan tsunami Indonesia 2011: Kabupaten Banyuwangi skor 38 (kelas rawan tinggi dengan peringkat 9 Nasional)

3. Indeks rawan bencana angin topan: Kabupaten Banyuwangi skor 42 (kelas rawan tinggi dengan peringkat 31 Nasional)

Kabupaten Banyuwangi memiliki daerah wisata pegunungan dan wisata pantai. Wisata pegunungan yaitu gunung Ijen yang menjadi daerah yang selalu menjadi primadona tujuan bagi wisatawan. Wisata pantai misalnya di daerah wisata Pulau Merah, Pantai Plengkung atau yang juga disebut dengan G-Land, Pantai Rajegwesi yang terletak di Desa Sarongan, Kecamatan Pesanggaran; Pantai Watu Dodol, Teluk Hijau atau Green Bay dan Pantai Pancer. Penanggulangan Bencana sudah menjadi perhatian pemerintah daerah Kabupaten Banyuwangi melalui Peraturan Daerah Kabupaten Banyuwangi Nomor 10 Tahun 2013 tentang Penanggulangan Bencana. Mengacu pada isu strategis pembangunan Kabupaten Banyuwangi tahun 2016-2021 yang dirumuskan dan penting untuk diperhatikan diantaranya yaitu belum terbangunnya sistem penanggulangan bencana. Mengingat Kabupaten Banyuwangi merupakan daerah dengan ancaman bencana baik tsunami, selain itu juga merupakan wilayah rawan bencana gunung berapi, puting beliung, tanah longsor, kekeringan maupun bencana kebakaran. Oleh karena itu diperlukan pembangunan sistem penanggulangan bencana yang diharapkan akan mampu mewujudkan pelayanan prima dalam bidang Penanggulangan Bencana di Daerah (BPBD Kabupaten Banyuwangi, 2016).

Peran serta masyarakat dalam penanggulangan bencana merupakan hak dan kewajiban masyarakat mendapat perlindungan dan kehidupan sosial yang harmonis, rasa aman, pendidikan, pelatihan dan keterampilan, informasi, pengambilan keputusan berkaitan dengan diri dan komunitasnya, melakukan pengawasan sesuai dengan mekanisme yang diatur dalam pelaksanaan penanggulangan bencana, memberikan informasi yang benar kepada publik serta melakukan kegiatan penanggulangan bencana yang bertujuan untuk menjamin terselenggaranya pelaksanaan penanggulangan bencana secara terencana, terpadu, terkoordinasi, dan menyeluruh dalam rangka memberikan perlindungan kepada masyarakat dari ancaman risiko dan dampak bencana. Peran serta masyarakat dalam penyelenggaraan penanggulangan bencana bertujuan untuk mendukung penguatan kegiatan penanggulangan bencana dan kegiatan pendukung lainnya secara berdaya guna, berhasil guna, dan dapat dipertanggungjawabkan. Peran serta masyarakat dalam penyelenggaraan penanggulangan bencana diatur dalam Peraturan Kepala BNPB Nomor 11 Tahun 2014. Dalam rangka mewujudkan Desa/Kelurahan Tangguh Bencana (DESTANA) di Kabupaten Banyuwangi, salah satu Indikator Kinerja Utama dalam Program Pengembangan Ketangguhan Masyarakat Menghadapi Bencana yaitu kapasitas masyarakat di kawasan rawan bencana Kabupaten Banyuwangi pada tahun 2016 sebesar 12.5\% (BPBD Kabupaten Banyuwangi, 2017). Berdasarkan data kapasitas masyarakat di kawasan rawan bencana Kabupaten 
Banyuwangi pada tahun 2016 tersebut menggambarkan pentingnya peningkatan kapasitas partisipasi Masyarakat dalam penanggulangan bencana dan sejalan dengan pesatnya bidang pariwisata Kabupaten Banyuwangi, maka perlu dilaksanakan peningkatan capacity building peran serta masyarakat dalam penanggulangan bencana di daerah wisata Kabupaten Banyuwangi untuk mendukung Desa/Kelurahan Tangguh Bencana (DESTANA). Tujuan kegiatan ini adalah Memberikan edukasi dan mendemonstrasikan tentang peran serta masyarakat dalam penanggulangan bencana di daerah wisata Kabupaten Banyuwangi untuk mendukung Desa/ Kelurahan Tangguh Bencana (DESTANA).

\section{METODE}

Cara penyelesaian masalah untuk peningkatan kapasitas partisipasi masyarakat dalam penanggulangan bencana di daerah wisata dengan cara pelatihan capacity building peran serta masyarakat dalam penanggulangan bencana. Peserta pelatihan ini terdiri dari :

1 Perangkat Desa/Kelurahan dari Kecamatan Licin, Kalipuro, dan Wongsorejo

2. Pemandu Wisata (Tour Guide) dari Agen Perjalanan Wisata (Tourism Travel Agency) Kegiatan pengabdian kepada masyarakat dilaksanakan di Balai Diklat PNS Licin, Kecamatan Licin, Kabupaten Banyuwangi. Kegiatan ini dilaksanakan pada tanggal 26 Oktober 2017 selama 8 jam (08.00-16.00 WIB). Data dikumpulkan melalui pretest, post test dan observasi. Data dianalisis secara deskriptif.

\section{PEMBAHASAN}

Peran serta masyarakat dalam penyelenggaraan penanggulangan bencana diatur dalam Peraturan Kepala BNPB Nomor 11 Tahun 2014. Peran serta masyarakat dalam penanggulangan bencana merupakan hak dan kewajiban masyarakat mendapat perlindungan dan kehidupan sosial yang harmonis, rasa aman, pendidikan, pelatihan dan keterampilan, informasi, pengambilan keputusan berkaitan dengan diri dan komunitasnya, melakukan pengawasan sesuai dengan mekanisme yang diatur dalam pelaksanaan penanggulangan bencana, memberikan informasi yang benar kepada publik serta melakukan kegiatan penanggulangan bencana yang bertujuan untuk menjamin terselenggaranya pelaksanaan penanggulangan bencana secara terencana, terpadu, terkoordinasi, dan menyeluruh dalam rangka memberikan perlindungan kepada masyarakat dari ancaman risiko dan dampak bencana. Peran serta masyarakat dalam penyelenggaraan penanggulangan bencana bertujuan untuk mendukung penguatan kegiatan penanggulangan bencana dan kegiatan pendukung lainnya secara berdaya guna, berhasil guna, dan dapat dipertanggungjawabkan.

Pelatihan ini dibagi menjadi dua tahap yaitu tahap paparan materi dan simulasi. Tahap pertama yaitu paparan materi yang bertujuan meningkatkan pengetahuan masyarakat tentang peran serta masyarakat dalam penanggulangan bencana di daerah wisata. Ada empat materi yang disampaikan oleh narasumber yaitu:

1. Overview Manajemen Bencana

2. Potensi dan Perkembangan Pariwisata di Kabupaten Banyuwangi

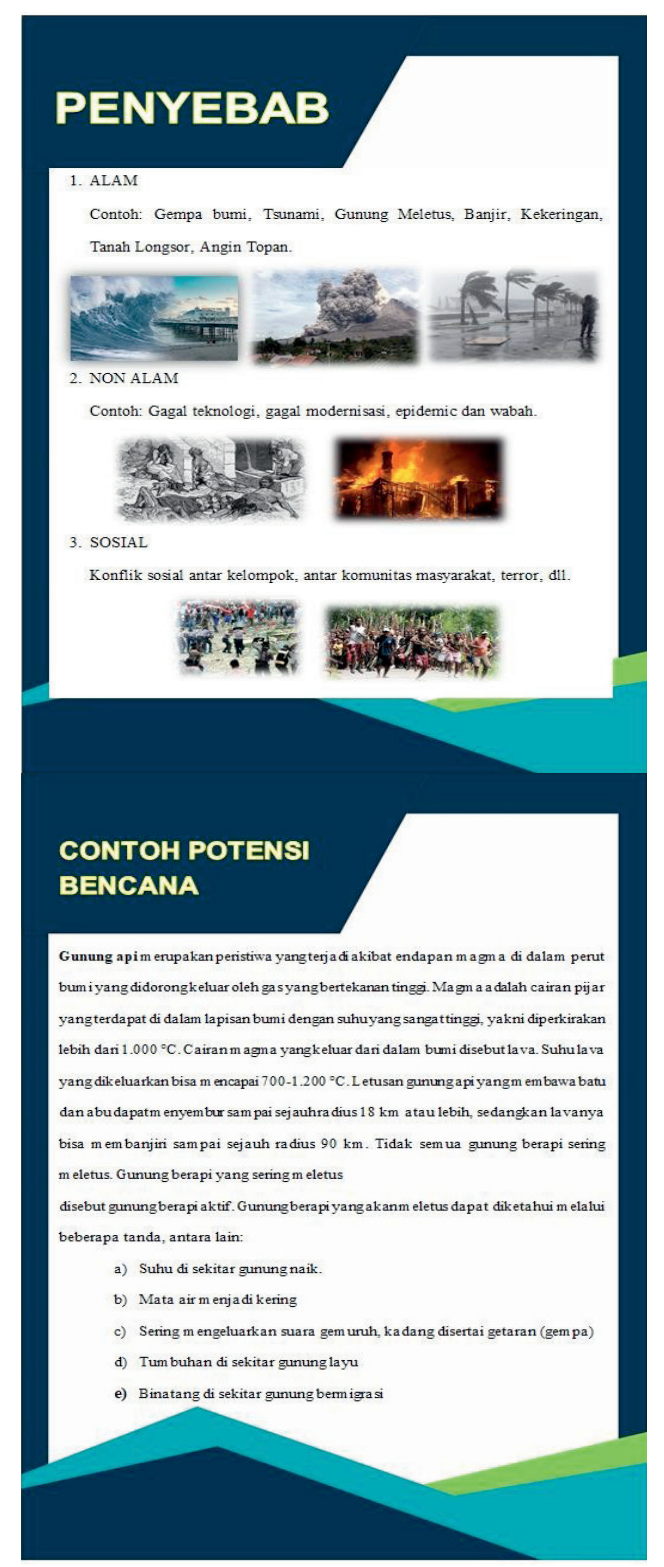

Sumber: Dokumentasi Panitia Pengabdian Kepada Masyarakat, 2017.

Gambar 1. Contoh Isi Booklet Manajemen Bencana 
3. Menjaga Keselamatan Pengunjung Kawasan Wisata gunung Ijen dari Kebencanaan

4. Peran serta masyarakat dalam penanggulangan bencana (Kegiatan Pra Bencana, Tanggap Darurat, dan Pasca Bencana)

Narasumber berasal dari Universitas Airlangga, Dinas Kebudayaan dan Pariwisata Kabupaten Banyuwangi, Balai Besar Konservasi Sumber Daya Alam (KSDA) dan Badan Penanggulangan Bencana Daerah (BPBD) Kabupaten Banyuwangi. Peserta mendapatkan print out materi dari masing-masing narasumber dan booklet manajemen bencana. Contoh booklet manajemen bencana sebagai berikut.

Masing-masing pemberian materi berdurasi satu jam dengan alokasi waktu 30 menit paparan materi dan 30 menit diskusi. Gambaran kegiatan pelatihan dapat dilihat pada gambar 2 dan 3 di bawah ini.



Sumber: Dokumentasi Panitia Pengabdian Kepada Masyarakat, 2017.

Gambar 2. Peserta Mendengarkan Materi dari Narasumber BPBD

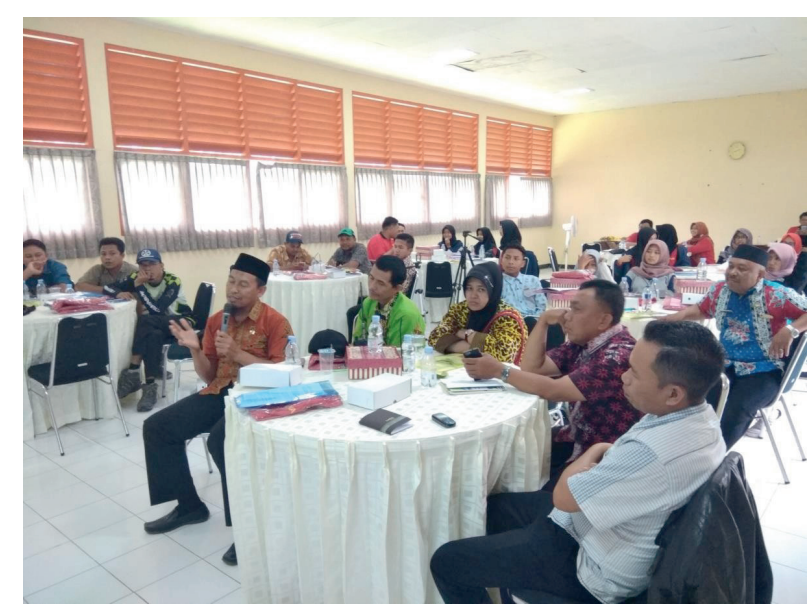

Sumber: Dokumentasi Panitia Pengabdian Kepada Masyarakat, 2017.

Gambar 3. Peserta Bertanya Kepada Narasumber
Tahap kedua yaitu simulasi. Simulasi partisipasi masyarakat dalam penanggulangan bencana dilaksanakan oleh peserta secara berkelompok. Game simulasi ini dilakukan dengan tujuan mendemonstrasikan peran serta masyarakat dalam penanggulangan bencana di daerah wisata Kabupaten Banyuwangi untuk mendukung Desa/Kelurahan Tangguh Bencana (DESTANA). Setiap kelompok diminta untuk melakukan pemetaan hal yang perlu dilakukan dalam kegiatan pra bencana, tanggap darurat, hingga pasca bencana. Kegiatan simulasi ini dilakukan selama 45 menit sekaligus dengan tahap pemaparan hasil diskusi setiap kelompok. Gambaran kegiatan simulasi dapat dilihat pada gambar 4 dan 5 ini.

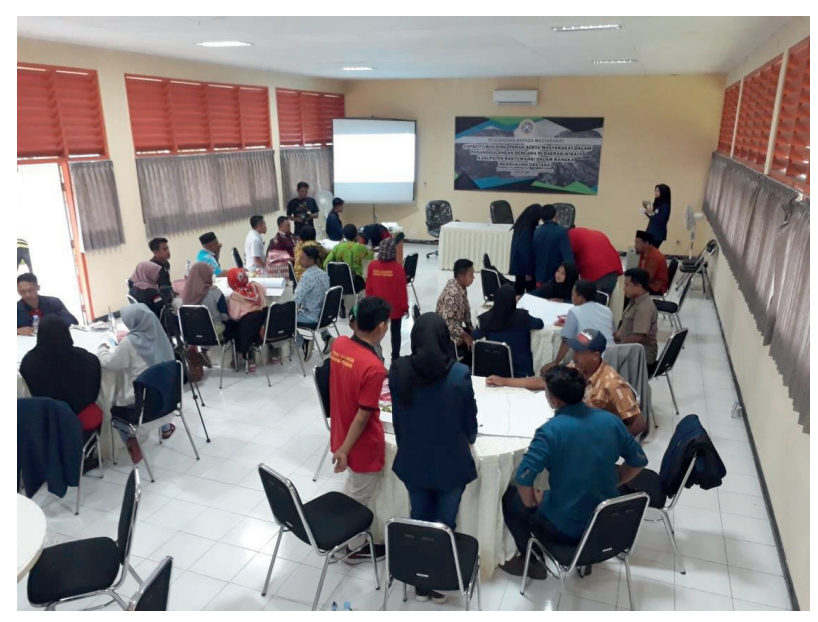

Sumber: Dokumentasi Panitia Pengabdian Kepada Masyarakat, 2017.

Gambar 4. Simulasi per Kelompok

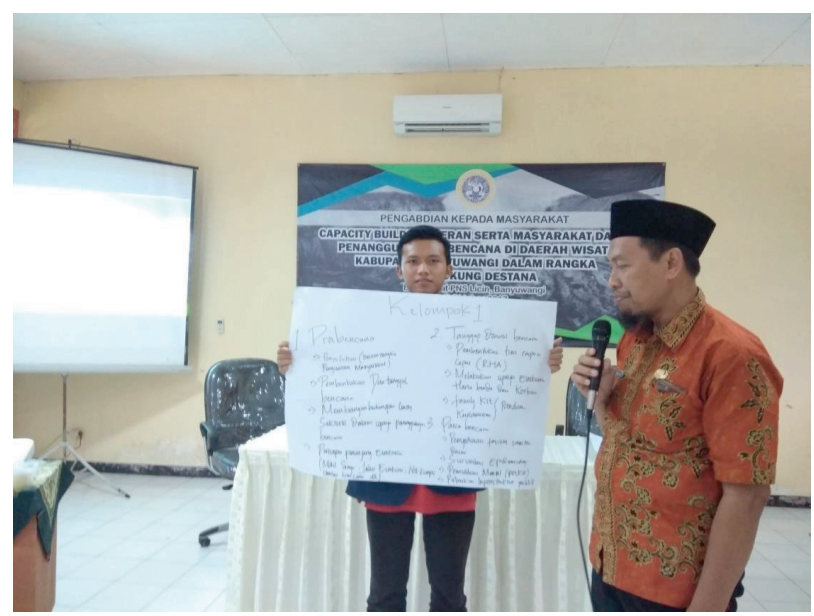

Sumber: Dokumentasi Panitia Pengabdian Kepada Masyarakat, 2017.

Gambar 5. Presentasi Hasil Simulasi 
Tabel 1. Evaluasi Kegiatan Pengabdian kepada Masyarakat



Hasil evaluasi kegiatan Pengabdian kepada Masyarakat dapat dilihat pada tabel 1 .

Berdasarkan tabel 1 di atas, dapat diketahui tingkat keberhasilan kegiatan pengabdian kepada masyarakat yaitu tercapainya tujuan pertama "Memberikan edukasi tentang peran serta masyarakat dalam penanggulangan bencana di daerah wisata Kabupaten Banyuwangi untuk mendukung Desa/Kelurahan Tangguh Bencana (DESTANA)" sebesar 90\% dan tujuan kedua "Mendemonstrasikan tentang peran serta masyarakat dalam penanggulangan bencana di daerah wisata Kabupaten Banyuwangi untuk mendukung Desa/ Kelurahan Tangguh Bencana (DESTANA)" sebesar 107\%.

Partisipasi masyarakat saat pra bencana digunakan mengetahui tanda-tanda kemungkinan bencana akan datang seperti terjadinya musim penghujan, kondisi di sekitar yang kemungkinan akan berakibat terjadi bencana. Jika masyarakat mengenali tanda-tanda tersebut dengan baik, tentu korban baik harta ataupun jiwa dapat diminimalisir. Akan tetapi bila masyarakat belum mengenali akan tandaanda akan terjadi bencana kemungkinan korban dapat bertambah baik harta ataupun jiwa (Ulum et al., 2007). Adanya masyarakat yang sudah berbasis kesiapsiagaan bencana diperlukan menurut Rajev (2014) karena:

1. Masyarakat adalah pihak pertama yang terkena dampak dan merespons paling awal terhadap kejadian bencana.

2. Masyarakat adalah target utama rencana mitigasi dan kesiapsiagaan

3. Masyarakat sebagai agent perantara pengetahuan di lingkungannya

4. Masyarakat yang paling mempunyai pengetahuan risiko dan kerentanan di lingkungannya
5. Masyarakat mempersiapkan peta risiko dan kerentanan serta perencanaannya yang sudah terhubung dengan kehidupan sehari-harinya

6. Masyarakat adalah penilai terbaik terhadap bahaya bencana

7. Masyarakat sebagai evaluator terbaik terhadap pemulihan bencana

8. Masyarakat mempunyai kemandirian dalam perencanaan dan program

9. Masyarakat memfasilitasi mobilisasi sosial yang mampu memberdayakan masyarakat.

10. Masyarakat mampu mengidentifikasi kelompok rentan. Peningkatan pengetahuan dan kesadaran masyarakat akan potensi ancaman di desa/kelurahan mereka dan akan kerentanan warga merupakan salah satu strategi dalam mewujudkan Desa/Kelurahan Tangguh Bencana sesuai dengan Peraturan Kepala BNPB Nomor 1 Tahun 2012 tentang Pedoman Umum Desa/Kelurahan Tangguh Bencana.

\section{SIMPULAN}

Kegiatan pengabdian kepada masyarakat ini mampu meningkatkan pengetahuan dan keterampilan masyarakat di daerah wisata tentang peran serta masyarakat dalam penanggulangan bencana di daerah wisata Kabupaten Banyuwangi untuk mendukung Desa/Kelurahan Tangguh Bencana (DESTANA). Berdasarkan hasil evaluasi kegiatan ini, maka rencana tahapan selanjutnya sebagai berikut. 
1. Melaksanakan replikasi kegiatan di daerah Kawasan Rawan Bencana (KRB) di Kabupaten Banyuwangi.

2. Bekerjasama dengan Badan Penanggulangan Bencana Daerah (BPBD) Kabupaten Banyuwangi untuk mengoptimalkan DESTANA.

3. Bersinergi dengan stakeholders terkait untuk melaksanakan kegiatan pengabdian kepada masyarakat sejenis.

\section{DAFTAR PUSTAKA}

BPBD. 2016. Rencana Strategis (RENSTRA) Badan Penanggulangan Bencana Daerah Tahun 2016-2021. Banyuwangi: BPBD.

BPBD Kabupaten Banyuwangi. 2017. Profil Badan Penanggulangan Bencana Daerah Tahun 2017. Banyuwangi: BPBD.

BPS Kabupaten Banyuwangi. Kecamatan Pesanggaran Dalam Angka 2015. Banyuwangi: BPS.
Peraturan Kepala Badan Nasional Penanggulangan Bencana Nomor 1 Tahun 2012 tentang Pedoman Umum Desa/ Kelurahan Tangguh Bencana.

Peraturan Kepala Badan Nasional Penanggulangan Bencana Nomor 11 Tahun 2014 tentang Peran serta Masyarakat dalam Penyelenggaraan Penanggulangan Bencana.

Peraturan Daerah Kabupaten Banyuwangi Nomor 10 Tahun 2013 tentang Penanggulangan Bencana.

Rajeev,M.M. 2014. Sustainability and Community Empowerment in Disaster Management. International Journal of Social Work and Human Services Practise Vol. 2 No. 6 pp.207-212.

Ramli, Soehatman. 2010. Manajemen Bencana (Disaster Management). Jakarta: PT. Dian Rakyat.

Ulum, et.al. 2017. Partisipasi Masyarakat Kelurahan Tinjomoyo Kecamatan Banyumanik Terhadap Upaya Penanggulangan Bencana Tanah Longsor. https:// journal.unnes.ac.id/sju/index.php/edugeo [Akses tanggal 15 Oktober 2017].

Undang-Undang Nomor 24 Tahun 2007 tentang Penanggulangan Bencana. 